\title{
ІСТОРІЯ, СЬОГОДЕННЯ ТА ПЕРСПЕКТИВИ РОЗВИТКУ ІНСТИТУТУ МЕДИКО-БІОЛОГІЧНИХ ПРОБЛЕМ ДВНЗ “ТЕРНОПІЛЬСЬКИЙ ДЕРЖАВНИЙ МЕДИЧНИЙ УНІВЕРСИТЕТ ІМЕНІ І. Я. ГОРБАЧЕВСЬКОГО МОЗ УКРАЇНИ"
}

\author{
С. Н. Вадзюк, І. Я. Папінко, І. Б. Паньків
}

ДВНЗ “Тернопільський державний медичний університет імені І. Я. Горбачевського МОЗ Украӥни”

\section{HISTORY, PRESENT AND FUTURE DEVELOPMENT PERSPECTIVES OF THE INSTITUTE OF MEDICOBIOLOGICAL PROBLEMS OF SHEI "TERNOPIL STATE MEDICAL UNIVERSITY BY I. YA. HORBACHEVSKY OF MPH OF UKRAINE"}

\author{
S. N. Vadziuk, I. Ya. Papinko, I. B. Pankiv \\ SHEI "Ternopil State Medical University by I. Ya. Horbachevsky of MPH of Ukraine"
}

\begin{abstract}
Навчально-науковий інститут медико-біологічних проблем створений у 2005 році як структурний підрозділ університету. Робота інституту спрямована на підготовку студентів як майбутніх висококваліфікованих фахівців і відповідає рівню розвитку медичної науки та вимогам суспільства, грунтується на введенні нових підходів до організації навчального процесу за свропейськими стандартами. Це дас змогу забезпечити конкурентоспроможність випускників вищих медичних навчальних закладів на вітчизняному та міжнародному ринках праці.
\end{abstract}

The educational scientific institute of medicobiological problems was created in 2005 , as a structural subdivision of the university. Work of the institute is aimed at teaching students, as highly skilled specialists in future and reflects the level of development of medical science, requirements of society, and is based on implementation of the new aproaches to educational process organization with European standards. It gives an opportunity to competitiveness of graduating students of higher medical educational structures on local and international labour-markets.

Вступ. Навчально-науковий інститут (ННI) медико-біологічних проблем розташований у біологічному корпусі університету і охоплює 4 кафедри з їх навчальними приміщеннями, лабораторіями та кабінетами. Також тут розміщені: бібліотека 3 комп'ютерним залом, навчальний музей, лекційна аудиторія, лабораторія мікробіологічних досліджень. До складу інституту ввійшли кафедри медичної біології, мікробіології, вірусології та імунології, нормальної фізіології, соціальної медицини, організації охорони здоров'я з медичною статистикою.

Основна частина. Керівництво інституту здійснює директор, який був обраний 29 серпня 2005 року на засіданні колективів кафедр шляхом таємного голосування. 3 перших днів і до теперішнього часу інститут очолює професор С. Н. Вадзюк. У своїй роботі він керується Конституцією України, Законом України "Про освіту", Положенням про державний вищий заклад освіти та іншими нормативно-правовими документами з питань вищої освіти.

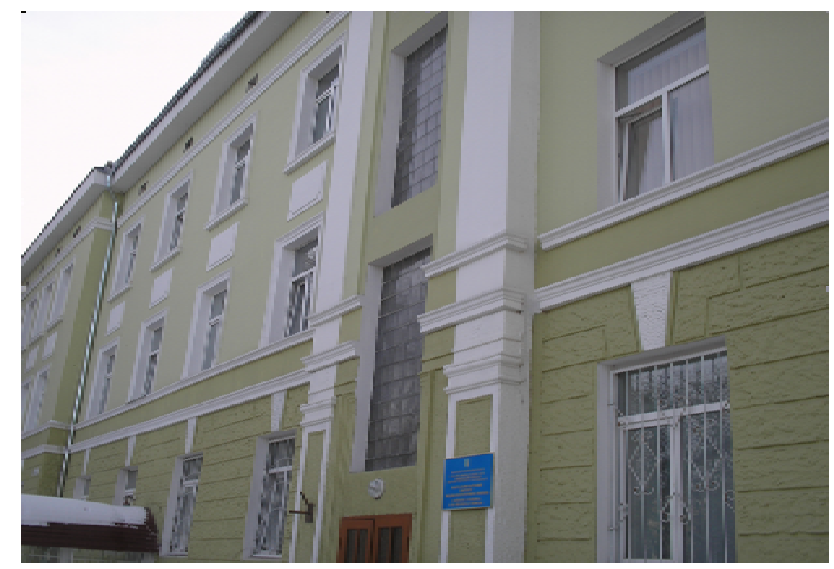

Puc. 1. Корпус інституту медико-біологічних проблем.

У навчально-науковому інституті була створена вчена рада, склад якої затверджувався вченою радою та ректором університету. До складу вченої ради входять: директор, заступники, завідувачі кафедр і всі викладачі, які мають наукові ступені і вчені зван-

(ㄷ) С. Н. Вадзюк, I. Я. Папінко, І. Б. Паньків 
ня. Протягом попередніх років склад вченої ради змінювався і на 01.01.2012 року складає 21 особу.

Робота вченої ради відбувається відповідно до плану, який складається і затверджується щорічно. У плані роботи вченої ради висвітлюються основні напрямки діяльності інституту у навчально-методичній, науково-дослідницькій та виховній роботі.

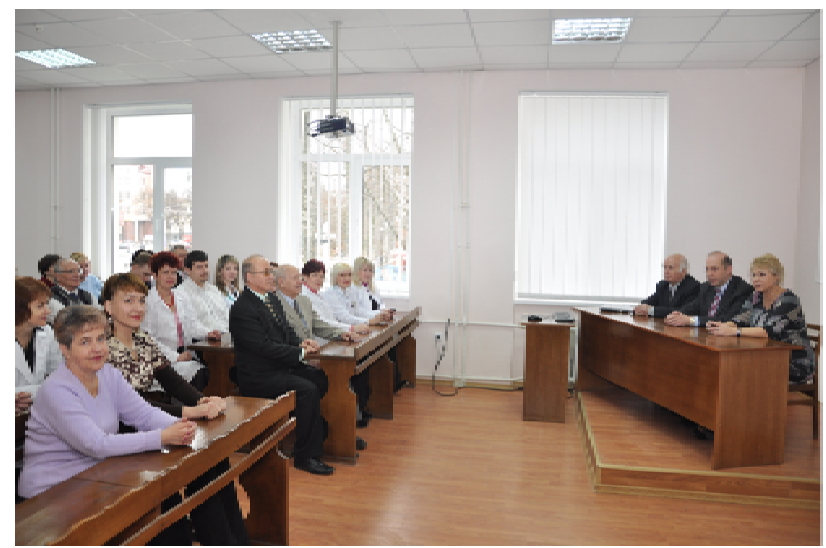

Puc. 2. Засідання вченої ради інституту медикобіологічних проблем.

В інституті працює циклова методична комісія, яку очолює заступник директора 3 навчальної роботи доц. Н. І. Ткачук. На засіданнях комісії, що відбуваються відповідно до щорічно затверджуваних планів роботи, розглядаються і обговорюються питання методичного забезпечення навчального процесу, методики проведення практичних занять та лекцій, критерії оцінювання знань студентів, підготовки навчальних підручників й посібників тощо.

За період діяльності ННІ медико-біологічних проблем відбулися значні зміни у навчальній роботі. Так, кафедри перейшли на навчання за методикою “єдиного дня", впроваджена Z-система навчання, створені тематичні навчальні кімнати-лабораторії, які забезпечені сучасним оснащенням. Всі лекції, які читаються трьома мовами, забезпечені мультимедійними презентаціями. Акцентована увага на засвоєння і оволодіння практичними навичками, які внесені у лінії практичних навичок - "Матрикули”. Широко використовується дистанційний тестовий контроль знань за системою "Moodle", для якого співробітники кафедр створили на одне практичне заняття понад 250 тестових завдань, ситуаційних задач та малюнків для всіх спеціальностей українською, російською та англійською мовами. Для семестрових тестових іспитів співробітники кафедр підготували тисячі тестових завдань трьома мовами, які були подані у Центр незалежного тестування. За цей період підготовлені і видані 3 підручники і 4 посібники, затверджені МОЗ України.

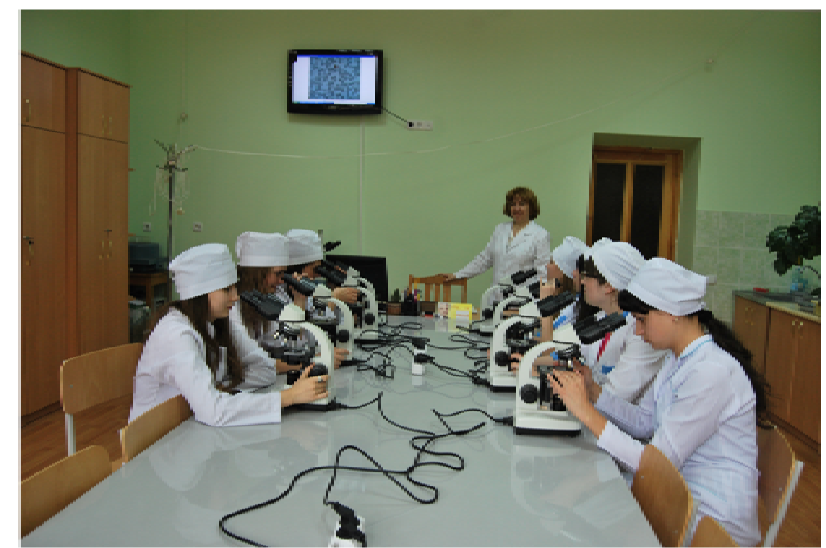

Puc. 3. Практичне заняття з циклу “Фізіологія крові".

Наукова робота ННІ медико-біологічних проблем передбачає планування і виконання дисертаційних робіт, виконання кафедральних та міжкафедральних науково-дослідних робіт, організацію та участь у проведенні науково-практичних конференцій, підготовку студентських наукових робіт.

Співробітники інституту беруть активну участь у наукових програмах України щодо реформування охорони здоров'я, прискореного розвитку первинної медико-санітарної допомоги як їі основної ланки, вивчення репродуктивного здоров'я нації з метою подолання демографічної кризи.

У період з 2007 по 2009 рр. проводилася науководослідна робота на тему “Організація медичної допомоги сільському населенню в умовах реформування галузі".

Одержані загальні результати дозволили визначити оптимальну потребу Тернопільської області в медичній допомозі, іï організаційну структуру та обгрунтовано оптимальну систему медичної допомоги сільському населенню з урахуванням її соціальної та економічної ефективності.

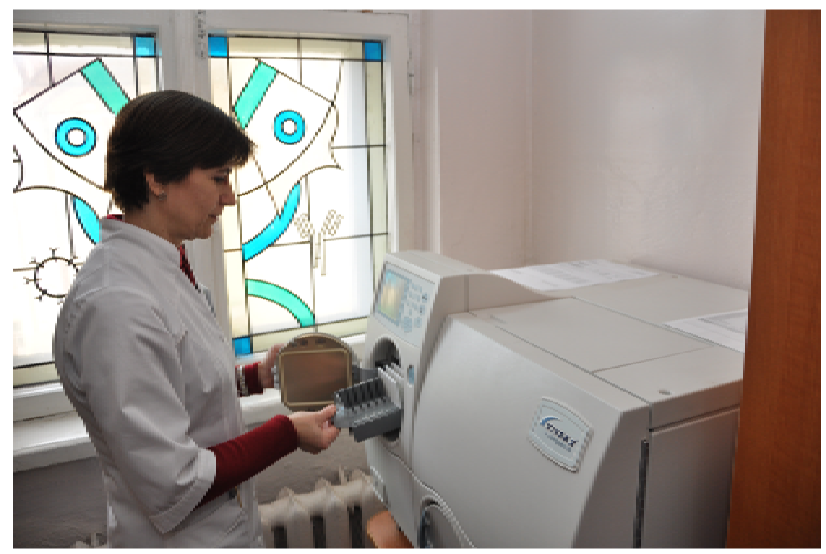

Puc. 4. Ідентифікація мікроорганізмів за допомогою апарата Vitek 2. 
32009 року інститут працює над виконанням запланованих науково-дослідних робіт за темами “Фізіологічні, мікробіологічні, клінічні та соціальні аспекти вивчення соматичних захворювань дітей, школярів, студентів та дорослого населення" i “Артеріальна гіпертензія та гіпертонічна хвороба у сільського населення як соціально-медичні проблеми".

У наукових дослідженнях особлива увага приділяється вивченню впливу гео-метеорологічних факторів на здоров' я студентів, їх мікробіологічний статус 3 акцентом на ураження стафілококовою інфекцією, дії соціальних факторів як чинників, що здатні істотно впливати на розвиток та перебіг хронічної патології серцево-судинної системи 3 акцентом на артеріальну гіпертензію і гіпертонічну хворобу.

Викладачі кафедр багато уваги приділяють виховній роботі студентів. У своїй роботі куратори груп звертають особливу увагу на національно-патріотичну складову виховного процесу. Регулярно проводяться організовані відвідування студентами краєзнавчого музею політв'язнів і репресованих, музею-садиби Соломії Крушельницької, музею-садиби І. Я. Горбачевського, зустрічі з працівниками правоохоронних органів, правознавцями, відомими людьми нашого краю. Традиційними стали еколого-краєзнавчі конференції, присвячені вивченню історії рідного краю, ознайомленню $з$ життям і діяльністю відомих людей, вихідців з рідних теренів, а також вивченню проблем екології та шляхів ії покращення.

При відвідуванні гуртожитків викладачі проводять бесіди про здоровий спосіб життя, правила гігієни, протипожежну безпеку, цікавляться проблемами життя у гуртожитку, допомагають у їх вирішенні. Організовуються круглі столи та диспути на теми "Правила поведінки, заборону куріння і вживання алкоголю в громадських місцях” “"Зупинимо СНІД разом".

Для удосконалення навчального процесу в ННI медико-біологічних проблем планується:

- збільшити резерв викладачів, які володіють англійською мовою;

- підготувати відеолекції для студентів дистанційної форми навчання трьома мовами;

- обладнати тематичні навчальні кімнати-лабораторії та оснащити їх потрібними приладами;

• написати англомовні підручники для англомовних студентів.

Висновок. У перспективі розвитку науки в ННI медико-біологічних проблем $є$ : атестація лабораторії психофізіологічних досліджень на базі кафедри нормальної фізіології. Передбачається, що новостворений підрозділ буде проводити роботи як фундаментального, так і практичного характеру, що забезпечить виконання сучасних перспективних завдань в контексті розвитку нашого університету; кооперування з вченими Тернопільського національного технічного університету ім. І. Пулюя, Вінницького національного медичного університету ім. М. І. Пирогова щодо проведення наукових досліджень; співпраця 3 HНI з фармакології, гігієни та медичної біохімії ім. М. П. Скакуна в організації та проведенні науковопрактичних конференцій “Довкілля і здоров’ я”. 